\title{
Prevention of cytokine-induced apoptosis by insulin-like growth factor-I is independent of cell adhesion molecules in HT29-D4 colon carcinoma cells - evidence for a NF- $\kappa$ B-dependent survival mechanism
}

\author{
F Garrouste ${ }^{1}$, M Remacle-Bonnet ${ }^{1}$, C Fauriat ${ }^{1}$, J Marvaldi ${ }^{1}$, \\ J Luis ${ }^{1}$ and G Pommier ${ }^{\star, 1}$ \\ 1 UMR CNRS 6032, Facultés de Médecine et de Pharmacie, Université de la \\ Méditerranée, Marseille, France \\ * Corresponding author: GJ Pommier, UMR CNRS 6032, Faculté de Pharmacie, \\ 27 Bd. J. Moulin, 13385 Marseille Cedex 5, France. Tel: 334918355 84; \\ Fax: 334918356 53; E-mail: gilbertopommier@pharmacie.univ-mrs.fr
}

Received 17.7.01; revised 13.12.01; accepted 10.1.02 Edited by G Ciliberto

\begin{abstract}
We have previously established that insulin-like growth factor (IGF)-I, -II and insulin exert a strong protective effect against tumor necrosis factor- $\alpha$ (TNF)-induced apoptosis in interferon- $\gamma$ (IFN)-sensitized HT29-D4 human colon carcinoma cells. In this study, we report that this effect was still operative when cells were cultured in the absence of integrin- and E-cadherinmediated cell-extracellular matrix and cell-cell interactions. In this model, IGF-I did not activate the focal adhesion kinase, whereas it induced tyrosine phosphorylation of the insulin receptor substrate-1 and activation of the extracellular signalrelated kinase 1 and 2, p38, phosphatidylinositol 3'-kinase and protein kinase B/Akt. However, the use of specific inhibitors indicated that these pathways did not play a role in the adhesion-independent IGF-I anti-apoptotic signal. In contrast, inhibition of the NF- $\kappa$ B activation induced a complete reversal of the IGF-I anchorage-independent protective effect. Correspondingly, IGF-I markedly enhanced the TNF- and IFN/TNFinduced NF- $k$ B-dependent interleukin-8 production. Our results provide evidence that IGF-I induces resistance against cytokine-induced cell death even in the absence of cell adhesion-mediated signaling. NF- $k$ B appears to be a key mediator of this anti-apoptotic effect that should contribute to the resistance of colon cancer cells to immune-destruction during metastasis.

Cell Death and Differentiation (2002) 9, 768-779. doi:10.1038/ sj.cdd. 4401022
\end{abstract}

Keywords: apoptosis; TNF; adhesion; colon carcinoma; IGF-IR

Abbreviations: IGF, insulin-like growth factor; dIGF-I, des-(1-3)IGF-I; IGF-IR, IGF-I receptor; IFN, interferon- $\gamma$; TNF, tumornecrosis factor- $\alpha$; ECM, extracellular matrix; mAb, monoclonal antibody; MAPK, mitogen-activated protein kinase; Erk, extra-cellular signal related kinase; IRS-1, insulin receptor substrate-1; FAK, focal adhesion kinase; PI3K, phosphatidylinositol 3'-kinase; Akt, product of the oncogene v-akt/protein kinase B; poly-HEMA, poly-(2hydroxyethyl methacrylate); PLL, poly-L-lysine; SFM, serum-free medium

\section{Introduction}

Cell death by apoptosis is an essential physiological process for maintaining tissue homeostasis by assuring a constant balance between cell production and cell loss. This is particularly true for the intestinal epithelium which is characterized by one of the most rapid cell turnover rates of any tissue of the body. ${ }^{1}$

'Instructive apoptosis' is a kind of apoptosis by which a death ligand such as tumor necrosis factor $\alpha$ (TNF) or Fas ligand interacts with its cognate cell surface death receptor belonging to the TNF receptor gene superfamily thus inducing apoptosis signals. ${ }^{2}$ This type of apoptosis is essential, especially for immune-based destruction, since the ligands of the TNF family are largely distributed among the immune system. ${ }^{3,4}$ In addition, chemotherapeutic drugs have been shown to induce the apoptosis of some types of cancer cells by up-regulating the expression of death ligands and receptors. ${ }^{5}$

Failures in the apoptosis pathways disable the deletion of genetically altered cells and contribute to carcinogenesis, and subsequently to the aggressive behaviors of malignant cells. $^{6,7}$ Moreover, cancer cell resistance to apoptosis is of major concern in cancer therapy because apoptosis is the main, if not the only, mechanism whereby drugs, radiations and immune effector cells induce the destruction of tumor cells. $^{7}$

The pathways that regulate apoptosis are complex, with networks of survival and death regulatory molecules working in a delicate balance to achieve a proper response..$^{7-9}$ In this way, it has been reported that resistance to apoptosis may result from an aberrant regulation of extracellular survival signals delivered by extracellular matrix (ECM), cell-cell interactions and growth factors. $^{10-12}$

Among the growth factors, insulin-like growth factor (IGF)-I, IGF-II and insulin have been reported to be powerful mediators of cell survival and inhibitors of apoptosis. ${ }^{13,14}$ The IGF-I receptor (IGF-IR) is the primary mediator of the anti-apoptotic action of IGF-I and IGF-II. ${ }^{14}$ Insulin was shown to exert an anti-apoptotic function at physiological concentrations through its own receptor, but also at high concentrations which are known to activate the IGF-IR. ${ }^{15}$ A protective effect of the activated IGF-IR against 
a wide variety of pro-apoptotic stimuli has been reported. The multiple anti-apoptotic signaling pathways used by this receptor may explain such a wide spread anti-apoptotic effect on death signals. ${ }^{16}$

The gastrointestinal tract is one of the most responsive target tissues for IGFs. ${ }^{17}$ In addition, in vivo and in vitro alterations of the IGF signaling have been shown to be associated with colorectal carcinoma suggesting a role for the IGF axis in the pathogenesis of this disease. ${ }^{18-20}$ By using the HT29-D4 human colon carcinoma cell model, we have shown that two key processes, enterocyte-like differentiation and cell migration, were under the control of the IGF system. ${ }^{21,22}$ In addition, we recently reported that IGF-I, IGF-II and insulin induce a strong resistance in HT29-D4 cells to apoptosis triggered by TNF in IFNsensitized cells. ${ }^{23}$

Increasing evidence shows that a collaboration between integrin-, E-cadherin- and growth factor-mediated signaling pathways is required for the cells to mount appropriate biological responses. ${ }^{24,25}$ In HT29-D4 cells, we previously determined that both integrin and $\mathrm{E}$ cadherin occupancy is necessary for cells to migrate in response to IGF-I. ${ }^{26}$

This study had two goals. The first was to determine whether the anti-apoptotic signals transmitted via the IGF$\mathrm{IR}$ in colon cancer cells requires a crosstalk with cellular adhesion molecules to prevent instructive apoptosis. We show that IGF-I and insulin can act independently from integrin-mediated cell-ECM and E-cadherin-mediated cellcell interactions to protect HT29-D4 cells from IFN/TNFinduced cell death. The second goal of this study was to determine the pathways downstream of IGF-IR that transmit the survival signals in an adhesion-independent manner. We report that IGF-I induces the phosphorylation (activation) of (i) insulin receptor substrate-1 (IRS-1); (ii) extracellular signal-related kinase (Erk) 1 and 2, and p38 mitogen-activated protein kinases (MAPK); and, (iii) p85subunit of the phosphatidylinositol $3^{\prime}$-kinase (PI3K) and its downstream target, the protein kinase B/Akt (Akt). However, our data indicate that the adhesion-independent anti-apoptotic effect of IGF-I depends on its ability to potentiate the TNF-induced activation of the NF- $\kappa \mathrm{B}$ pathway only.

\section{Results}

All the experiments described below were done with cells that were detached from monolayers by the use of EDTA, before seeding on defined ECM ligands, poly-L-lysine (PLL) or polyHEMA in serum-free medium (SFM) as described in Materials and Methods. PLL was used as a non-specific substratum, the poly-cationic nature of which prevents the engagement of integrins in the attached cells, ${ }^{27}$ while poly-HEMA was used to prevent cell attachment to a substratum because its uniformly nonionic nature prevents matrix deposition. ${ }^{28}$ Cells plated on fetal calf serum (FCS)-coated dishes were used as controls. Des-(1-3)-IGF-I (dIGF-I) was used instead of IGF-I because this N-terminally truncated IGF-I analog binds to IGF-IR with the same affinity as native IGF-I but does not bind to any of the IGF binding proteins secreted by the HT29-D4 cells. ${ }^{21}$

\section{HT29-D4 cells are resistant to anoikis}

We first determined the sensitivity of HT29-D4 cells to anoikis, a form of apoptosis induced by disruption of epithelial cellECM and cell - cell interactions. ${ }^{11}$ For this purpose, cells were plated on individual defined ECM ligands, PLL or poly-HEMA, and apoptosis was determined by flow cytometric analysis of PI-stained nuclei as described in Materials and Methods. Figure 1A, open bars, shows that the survival of HT29-D4 cells cultured in SFM on vitronectin or fibronectin was not different as compared to control cells (>97\%). When the cells were cultured on laminin-1 or type IV collagen, the basal cell survival was slightly lower than in control cells though remaining substantial ( $>93 \%)$. This was also the case when the cells were seeded on PLL or poly-HEMA (>95\%), and this was true for at least 10 days (not shown). However, it might be argued that cells cultured on PLL or poly-HEMA may elaborate endogenous ECM components that could suppress apoptosis through HT29-D4 cell-expressed integrin receptors, i.e., $\alpha_{1} \beta_{1}, \alpha_{2} \beta_{1}, \alpha_{3} \beta_{1}, \alpha_{6} \beta_{4}, \alpha_{v} \beta_{5}$ and $\alpha_{v} \beta_{6}$ integrins. ${ }^{27}$ Thus, we verified that the cell survival was not affected by a mixture of function-blocking mAbs to $\alpha_{\mathrm{v}}, \alpha_{6}$ and $\beta_{1}$ integrin subunits (Figure 1B, open bars, lanes INT). HT29-D4 cells cultured on poly-HEMA formed large, compact multicellular aggregates by $\sim 15 \mathrm{~h}$ (Figure 1C,a). Addition of the function-blocking antiE-cadherin MB-2 mAb completely prevented the formation of these aggregates. In these conditions, there were only weakly aggregated spheroids with individual cells clearly visible (Figure $1 \mathrm{C}, \mathrm{b}$ ). In contrast, addition of the mixture of antiintegrins mAbs did not interfere with the cell aggregation (not shown). Thus, the formation of multicellular aggregates in anchorage-independent conditions involved functional Ecadherin, which agrees with previous reports. ${ }^{12}$ It has been reported that hindering the formation of these E-cadherinmediated cell - cell contacts induces apoptosis in cells having lost cell-matrix signaling. ${ }^{12}$ However, the addition of MB-2 mAb to HT29-D4 cells cultured on poly-HEMA or PLL did not affect their survival for at least $48 \mathrm{~h}$ (Figure 1B, open bars, lanes $\mathrm{CADH}$ ).

Thus, the loss of cell-ECM and cell-cell contacts is not sufficient for inducing a significant apoptotic cell death in HT29-D4 cells, at least within the experimental conditions used here.

\section{HT29-D4 cells cultured in independence of cell-ECM and cell-cell interactions are sensitive to IFN/TNF-induced apoptosis}

HT29-D4 and the parental HT-29 cells, cultured on regular culture dishes have been shown to be totally resistant to the killing by TNF unless they are first sensitized by IFN. ${ }^{23,29,30} \mathrm{~A}$ same observation was made when the cells were cultured on a defined ECM ligand, PLL or poly-HEMA. However, the extent of apoptosis induced by TNF in combination with IFN was significantly increased as compared to control cells cultured on FCS-coated plates $(P<0.01)$ (Figure $1 \mathrm{~A}$, solid bars). Addition of anti-integrins (Figure 1B, solid bars, lanes INT) or anti-E-cadherin (Figure 1B, solid bars, lanes $C A D H$ ) $m A b s$ to the cells cultured on either poly-HEMA or PLL did not further increase significantly the extent of IFN/TNF-induced 
$\mathbf{A}$

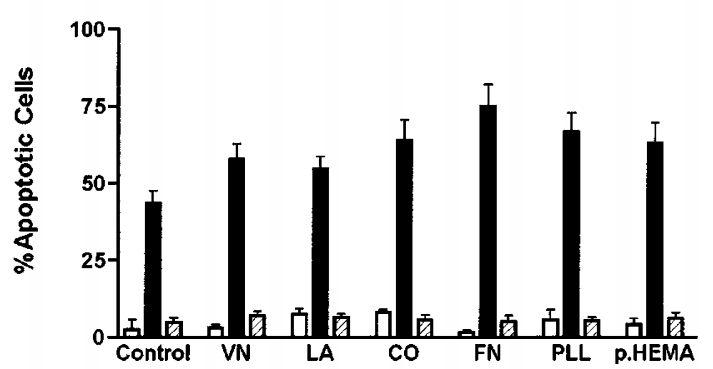

B

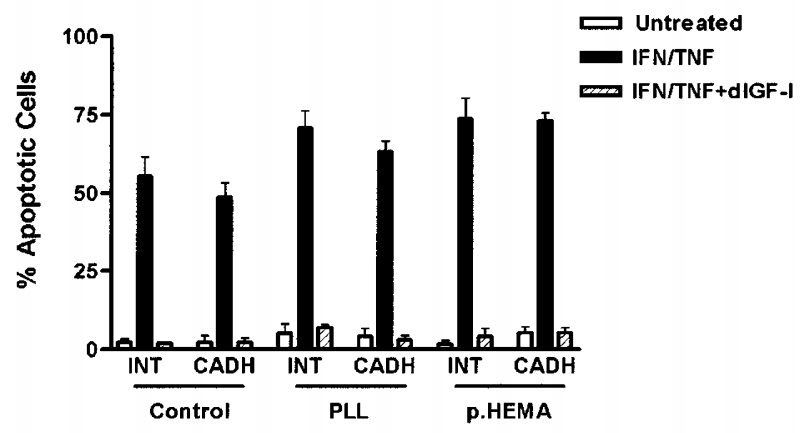

C

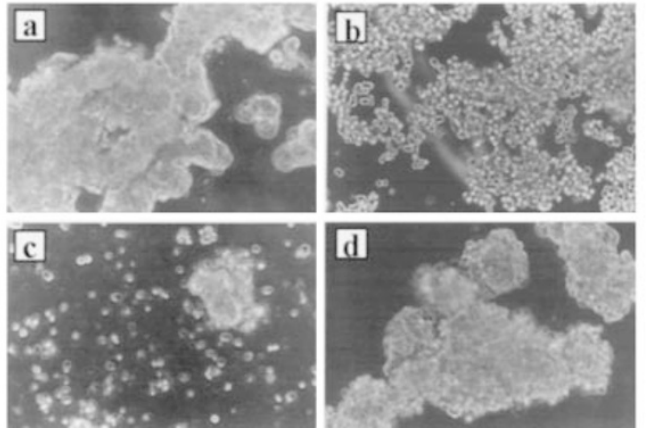

Figure 1 IGF-I induces resistance against IFN/TNF-mediated apoptosis in the absence of integrin- and E-cadherin-mediated signals. Tissue culture plastic wells were coated with vitronectin (VN), laminin-1 (LA), type IV collagen (CO), fibronectin (FN), PLL, poly-HEMA (p.HEMA) or 10\% FCS (Control), as described in Materials and Methods. Cells were plated for $5 \mathrm{~h}$ on these matrices in SFM (A), without or (B), with anti- $\alpha_{v},-\alpha_{6}$ and $-\beta_{1}$ mAbs (INT) or anti$\mathrm{E}$-cadherin MB-2 mAb (CADH). The cells were then left untreated (open bar) or 5 -min pulse-treated with IFN $(40 \mathrm{ng} / \mathrm{ml})$, and then incubated for $24 \mathrm{~h}$ with TNF $(4.0 \mathrm{ng} / \mathrm{ml})$ in the absence (solid bar) or presence (hatched bar) of dIGF$(50 \mathrm{ng} / \mathrm{ml})$. Apoptotic cells in the culture were quantified by a flow cytometric assay as described in Materials and Methods. Values are the mean \pm S.D. from three independent experiments performed in duplicate. (C) Multicellular aggregate formation of HT29-D4 cells in suspension is mediated by $\mathrm{E}$ cadherin-dependent cell-cell interactions. HT29-D4 cells were plated on polyHEMA-coated plates. After $24 \mathrm{~h}$ of culture in suspension, cells were photographed at $\times 200$. Depicted are (panel a), untreated cells; (panel b), cells treated with $1.0 \mu \mathrm{g} / \mathrm{ml}$ anti-E-cadherin MB-2 mAb; (panel c), IFN/TNFtreated cells; (panel d), IFN/TNF-treated cells in the presence of dIGF-I. Representative sections of each culture were selected

apoptosis. These results are in agreement with the well documented survival function of ECM. ${ }^{11}$

We report above that HT29-D4 cells seeded on polyHEMA formed E-cadherin-mediated multicellular aggre- gates (Figure 1C,a). When these cells were stimulated by IFN/TNF, apoptosis was accompanied by the complete disappearance of these multicellular aggregates and numerous single cells with only some small cell aggregates remaining loosely condensed were visible (Figure $1 \mathrm{C}, \mathrm{c}$ ).

Thus, although HT29-D4 cells have acquired resistance to anoikis, they remained fully responsive to the 'instructive apoptosis' induced by a combination of IFN and TNF in the absence of adhesion molecule-induced signaling.

\section{IGF-I and insulin induce resistance to IFN/TNF-induced apoptosis in HT29-D4 cells independently of cell-ECM and cell-cell interactions}

We recently showed that IGFs and insulin induced a complete resistance against IFN/TNF-induced apoptosis in HT29-D4 cells cultured in standard conditions. ${ }^{23}$ Figure $1 \mathrm{~A}$ (hatched bars) shows that the addition of dIGF-I (50 ng/ml) to IFN/TNFtreated HT29-D4 cells also induced a potent resistance (>85\%) whatever the defined ECM ligand on which HT29D4 cells were plated. It is worth noting that the IGF-I-induced resistance was also considerable $(>90 \%)$ when the cells were placed under conditions that denied them interactions with ECM, i.e., plated on PLL or poly-HEMA (Figure 1A).

Moreover, dIGF-I prevented the IFN/TNF-induced disruption of the multicellular aggregates observed in HT29-D4 cells plated on poly-HEMA (Figure 1C,d). The microscopic appearance of these cells was essentially identical to that of untreated control cells. Therefore, it might be hypothesized that IGF-I exerted its anti-apoptotic effect by inducing $\mathrm{E}$-cadherin-mediated survival signals in the multicellular aggregates. However, addition of the anti-E-cadherin MB-2 mAb, which blocked the formation of the compact cellular aggregates (Figure 1C,b), did not prevent the dIGF-I antiapoptotic effect whether the cells were seeded on polyHEMA or PLL (Figure 1B, hatched bars, lanes $C A D H$ ). Neither did addition of anti-integrins mAbs to the cells cultured on either poly-HEMA or PLL affect the dIGF-I antiapoptotic effect (Figure 1B, hatched bars, lanes INT).

Figure 2 shows the survival dose-response curves of IFN/TNF-treated cells in the presence of dIGF-I and insulin when the cells were plated on PLL. dIGF-I and insulin inhibited IFN/TNF-mediated apoptosis with an $\mathrm{IC}_{50}$ of 0.15 and $0.55 \mathrm{nM}$, respectively. Identical rates of protection were observed when the cells were seeded on poly-HEMA (not shown). These values are similar to that found when survival was evaluated in standard HT29-D4 cell monolayers. $^{23}$

Thus, we conclude that neither integrin- nor E-cadherinmediated signaling is required to sustain the survival effect of IGF-I and insulin in HT29-D4 cells submitted to the proapoptotic IFN /TNF treatment.

\section{Signaling pathways triggered by IGF-I in the absence of cell-ECM and cell-cell interactions}

We next determined if IGF-I was able to trigger its downstream signaling pathways in the absence of signals derived from ECM or neighboring cells. For this purpose, we plated 
HT29-D4 cells on PLL and measured the activation by IGF-I of proximal (IRS-1) and distal (MAPK and PI3K/Akt) signaling elements that are part of the consensus IGF-I-mediated signaling pathways. ${ }^{14,31}$ Moreover, since the survival signals from ECM have been widely reported to be transduced by the integrin/focal adhesion kinase (FAK) signaling pathway, ${ }^{32}$ we also assessed whether IGF-I was able to activate FAK in an ECM/integrin independent manner.

IRS-1 phosphorylation Tyrosine phosphorylation of the adaptator protein IRS-1 occurs optimally in HT29-D4 cells within 1 min of IGF-I treatment. ${ }^{23}$ Figure 3 shows that stimulation by various doses of dIGF-I led to a comparable extent of tyrosine phosphorylation of IRS-1 in control cells and cells plated on PLL. Thus, IGF-I-induced tyrosine phosphorylation of IRS-1 is not influenced by cell-ECM interactions in HT29-D4 cells.

Phosphorylation of MAPK The activation of MAPK, Erk (p44 Erk-1 and p42 Erk-2) and p38, was determined by using Abs that specifically detect the phosphorylated forms of these kinases. Figure 4 shows a constitutive activation of both Erk-1

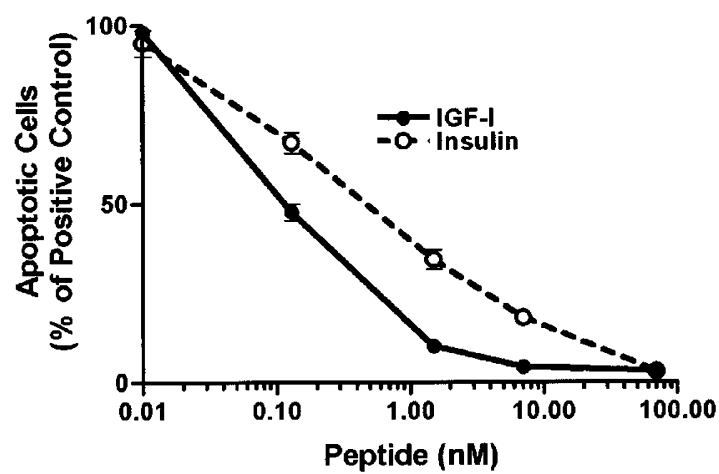

Figure 2 Dose-dependent anti-apoptotic effect of IGF-I and insulin in the absence of ECM survival signals. HT29-D4 cells were plated for $5 \mathrm{~h}$ on PLLcoated plates, then 5-min pulse-treated with IFN $(40 \mathrm{ng} / \mathrm{ml})$, and then incubated for $24 \mathrm{~h}$ with TNF $(4.0 \mathrm{ng} / \mathrm{ml})$ in the presence of various concentrations of dIGF-I (solid line) or insulin (dotted line). Apoptotic cells in the culture were quantified by a flow cytometric assay as described in Materials and Methods. For purposes of comparison, an arbitrary value of $100 \%$ was given to the apoptosis measured in the absence of added survival peptide. Values are the mean \pm S.D. from three independent experiments performed in duplicate

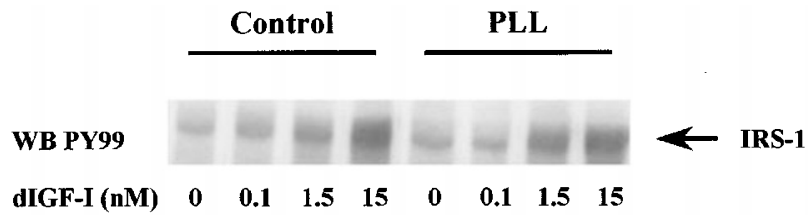

Figure 3 IGF-I-stimulated tyrosine phosphorylation of IRS-1 is independent on cell interactions with ECM. HT29-D4 cells were plated for $5 \mathrm{~h}$ on either $10 \%$ FCS- (Control) or PLL-coated plates (PLL), then stimulated for 1.0 min with the indicated concentrations of dIGF-I. Cell lysates were analyzed by immunoblotting with anti-phosphotyrosine mAb (WB PY 99) as described in Materials and Methods; arrow, position of IRS-1 and -2 in HT29-D4 cells, which has been previously reported in many other colon cancer cell lines. ${ }^{33}$ The extent of phosphorylation of Erk-1 and Erk-2 was further increased, and was maximal 30 min after addition of dIGF-I with a return to basal levels at $60 \mathrm{~min}$. p38 was also phosphorylated in HT29-D4 cells stimulated by dIGF-I, and the activation was sustained for at least $60 \mathrm{~min}$. In addition, Figure 4 indicates that there was no significant difference in Erk phosphorylation by dIGF-I between control and ECM-independent cells, while phosphorylation of p38 was even more pronounced in cells cultured on PLL. Thus, contact between HT29-D4 cells and $\mathrm{ECM}$ is not required for IGF-I to activate the MAPK cascades, Erk and p38.

Phosphorylation of PI3K and Akt It has been shown in several cell types that PI3K and its downstream target Akt (also known as $\mathrm{PKB}$ ) are required for preventing apoptosis. ${ }^{34,35}$ Using an Ab specific for phosphorylated Akt, we found that dIGF-I induced a sustained strong activation of Akt (Figure 5A). The p85 subunit of PI3K was tyrosine phosphorylated within $5 \mathrm{~min}$ of dIGF-I treatment as determined by immunoprecipitating PI3K with an anti-PI3K $\mathrm{Ab}$, followed by immunoblotting with $\mathrm{mAb}$ to phosphotyrosine (PY 99) (Figure 5B). Moreover, Figure 5 shows that dIGF-I induced a similar extent of phosphorylation of these kinases whether the cells were cultured in standard conditions or on PLL. Thus, these results point out that activation of the PI3K/ Akt pathway by IGF-I is independent of cell-ECM interactions in HT29-D4 cells.

FAK phosphorylation As shown on Figure 6, tyrosine phosphorylation of FAK was revealed by immunoprecipitation using an anti-FAK $A b$, followed by
Control

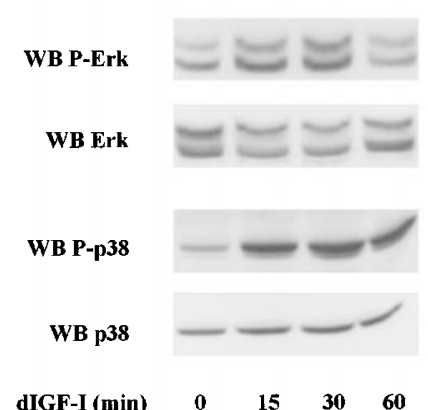

PLL

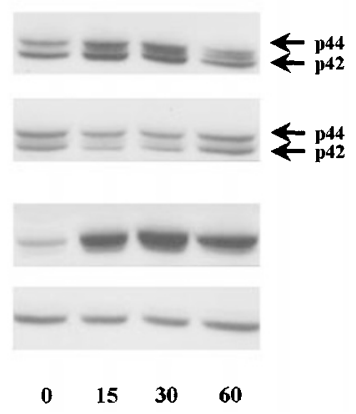

Figure 4 IGF-I induces phosphorylation of Erk and p38 MAPK in both control and ECM-independent HT29-D4 cells. Cells were plated for $5 \mathrm{~h}$ on either $10 \%$ FCS- (Control) or PLL-coated plates (PLL), then stimulated with dIGF-I (50 ng/ $\mathrm{ml}$ ) for varying time periods $(0-60 \mathrm{~min})$. The phosphorylation of Erk and p38 was evaluated in cell lysates by immunoblotting with Abs to phosphorylated Erk (WB P-Erk) or phosphorylated p38 (WB P-p38) as described in Materials and Methods. The blots were stripped and reprobed with anti-Erk (WB Erk) and anti-p38 (WB p38) Abs. The signal from the experiments was quantitated by scanning densitometry and the level of P-Erk and P-p38 in each sample was normalized to the level of Erk and p38, respectively. The maximal level of phosphorylation expressed as fold induction over the basal phosphorylation in unstimulated cells was 6.7 and 5.3 after 30 -min of IGF-I stimulation for p44 Erk-1, 2.4 and 2.8 for p42 Erk-2, and 2.5 and 8.0 for p38 in control and PLL cells, respectively 
$\underline{\mathbf{A}}$

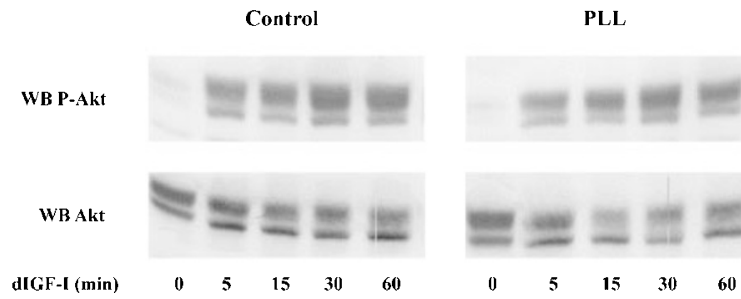

$\underline{B}$

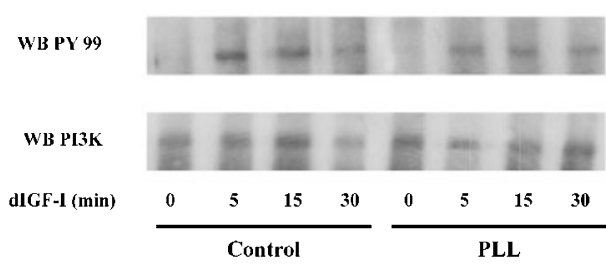

Figure 5 IGF-I induces phosphorylation of (A) Akt and (B) PI3K in both control and ECM-independent HT29-D4 cells. Cells were plated for $5 \mathrm{~h}$ on either $10 \%$ FCS- (Control) or PLL-coated plates (PLL), then stimulated with dIGF-I (50 ng/ml) for varying time periods $(0-60 \mathrm{~min})$. (A) Phosphorylation of Akt was evaluated in cell lysates by immunoblotting with $A b$ to phosphorylated Akt (WB P-Akt) as described in Materials and Methods. The blots were stripped and reprobed with anti-Akt Ab (Akt). (B) Phosphorylation of PI3K (p85) was evaluated in cell lysates after immunoprecipitation with anti-PI3K Ab (IPP PI3K) followed by immunoblotting with anti-phosphotyrosine mAb (WB PY99) as described in Materials and Methods. The blots were stripped and reprobed with anti-PI3K Ab (WB PI3K). The signal from the experiments was quantitated by scanning densitometry and the level of P-Akt and P-PI3K in each sample was normalized to the level of Akt and PI3K, respectively. The maximal level of phosphorylation expressed as fold induction over the basa phosphorylation in unstimulated cells was 29.3 and 31.2 after 30-min of IGF-I stimulation for Akt, and 15.2 and 13.2 after 5 min of IGF-I stimulation for PI3K in control and PLL cells, respectively

immunoblotting with an anti-phosphotyrosine mAb (PY 99). As expected for ECM-anchored cells, FAK was phosphorylated in control adherent HT29-D4 cells (Figure $6 \mathrm{~B}$, lane Control). Moreover, the addition of dIGF-I induced a small but significant increase in $F A K$ phosphorylation (Figure 6A, lanes Control). In contrast, when HT29-D4 cells were plated onto PLL or poly-HEMA, the basal tyrosine phosphorylation of FAK was barely detectable (Figure $6 \mathrm{~A}$ and $\mathrm{B}$, lanes PLL and pHEMA). This observation confirms that both substrata are quite suitable for culturing cells lacking interactions with ECM. It also indicates that cell-cell interactions induced by culturing cells in suspension (Figure 1C,a) failed to trigger FAK phosphorylation (Figure 6B, lane pHEMA). However, what is important to note is that dIGF-I did not induce a significant increase in FAK phosphorylation, whether the cells were plated onto PLL (Figure 6A) or poly-HEMA (Figure 6B). Thus, ECM-independence of the IGF-I anti-apoptotic signaling cannot be ascribed to its capability to activate FAK in a manner mimicking the integrin/FAK-mediated survival signaling.

We next determined whether E-cadherin-mediated cellcell interactions were required for the efficiency of the IGFI signaling. We found that a $6-h$ preincubation of the cells with the anti-E-cadherin MB-2 mAb had no significant
IPP FAK

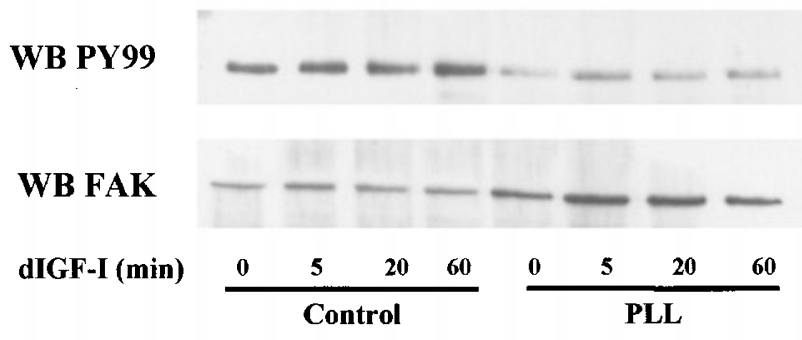

$\underline{\text { B }}$

WB PY99

WB FAK

Control PLL pHEMA pHEMA
Figure 6 Tyrosine phosphorylation of FAK in response to IGF-I occurs only in HT29-D4 cells cultured on ECM. (A) Cells were plated for $5 \mathrm{~h}$ on either $10 \%$ FCS (Control)- or PLL-coated plates (PLL), then stimulated with dIGF-I (50 ng/ $\mathrm{ml}$ ) for varying time periods $(0-60 \mathrm{~min})$; (B) Cells were plated on $10 \%$ FCS (Control)-, PLL- or poly-HEMA (pHEMA)-coated plates without or with $50 \mathrm{ng} /$ $\mathrm{ml}$ of dIGF-I for $24 \mathrm{~h}$. Cell lysates were immunoprecipitated with anti-FAK Ab (IPP FAK), followed by immunoblotting with anti-phosphotyrosine mAb (WB PY 99) as described in Materials and Methods. The blots were stripped and reprobed with anti-FAK Ab (WB FAK). The signal from the experiment shown in (A) was quantitated by scanning densitometry and the level of P-FAK in each sample was normalized to the level of FAK. The maximal level of phosphorylation expressed as fold induction over the basal phosphorylation in unstimulated cells was 6.8 and 0.7 after 60 -min of IGF-I stimulation in control and PLL cells, respectively

effect on the tyrosine phosphorylation of IRS-1 and the activation of MAPK, PI3K, Akt and FAK by dIGF-I (data not shown).

Taken together, our results indicate that neither cellECM interactions nor intercellular E-cadherin contacts are required for IGF-I to induce phosphorylation of IRS-1, and activation of MAPK (Erk and p38) and PI3K/Akt signaling pathways. In contrast, the activation of FAK in response to IGF-I is restricted to cells contacting ECM.

\section{Roles of PI3K, MAPK and NF- $\kappa$ B in the ECM-independent anti-apoptotic signaling of IGF-I}

To begin to determine the mechanisms by which the IGF-I anti-apoptotic effect is transduced in HT29-D4 cells in the absence of ECM-mediated survival signals, we used pharmacological inhibitors of several signaling pathways: (i) PD098059, an inhibitor of the activation of MAPK/Erk kinase (MEK) thus suppressing Erk-1 and Erk-2 kinase activities; $^{36}$ (ii) SB203580, a specific inhibitor of p38 MAPK; $^{37}$ (iii) LY294002 and wortmannin which are specific inhibitors of $\mathrm{PI} 3 \mathrm{~K} ;{ }^{38}$ (iv) BAY11-7082, a drug inhibiting $\mathrm{I}_{\kappa} \mathrm{B}$ phosphorylation thus preventing $\mathrm{NF}-\kappa \mathrm{B}$ activity. ${ }^{39}$ 
First, we observed that none of these inhibitors affected the basal cell survival (Figure 7). PD098059, LY294002 and BAY11-7082 increased the degree of apoptosis induced by IFN/TNF whereas SB203580 decreased it, and this was independent of cell-ECM interactions (Figure 7). Thus, MAPK, PI3K and NF- $\kappa \mathrm{B}$ constitute cell death regulatory pathways that modulate the extent of the IFN/ TNF-induced apoptosis in HT29-D4 cells, which is in agreement with our previous findings. ${ }^{23}$

Figure 7A shows that in control attached HT29-D4 cells, PD098059 $(100 \mu \mathrm{M})$, SB203580 $(20 \mu \mathrm{M})$, and BAY11-7082 $(50 \mu \mathrm{M})$ were able to partially reverse (from 40 to $60 \%$ ) the protective effect of dIGF-I against IFN/TNF-induced apoptosis. In contrast, LY294002 $(10 \mu \mathrm{M})$ and wortmannin (0.1 $\mu \mathrm{M}$; not shown) did not. Figure 7B shows the effects of the same kinase inhibitors in cells plated on PLL: none of PD098059, SB203580, LY294002 and wortmannin (this latter, not shown) was able to interfere with the dIGF-Imediated anti-apoptotic signaling. In contrast, BAY11-7082
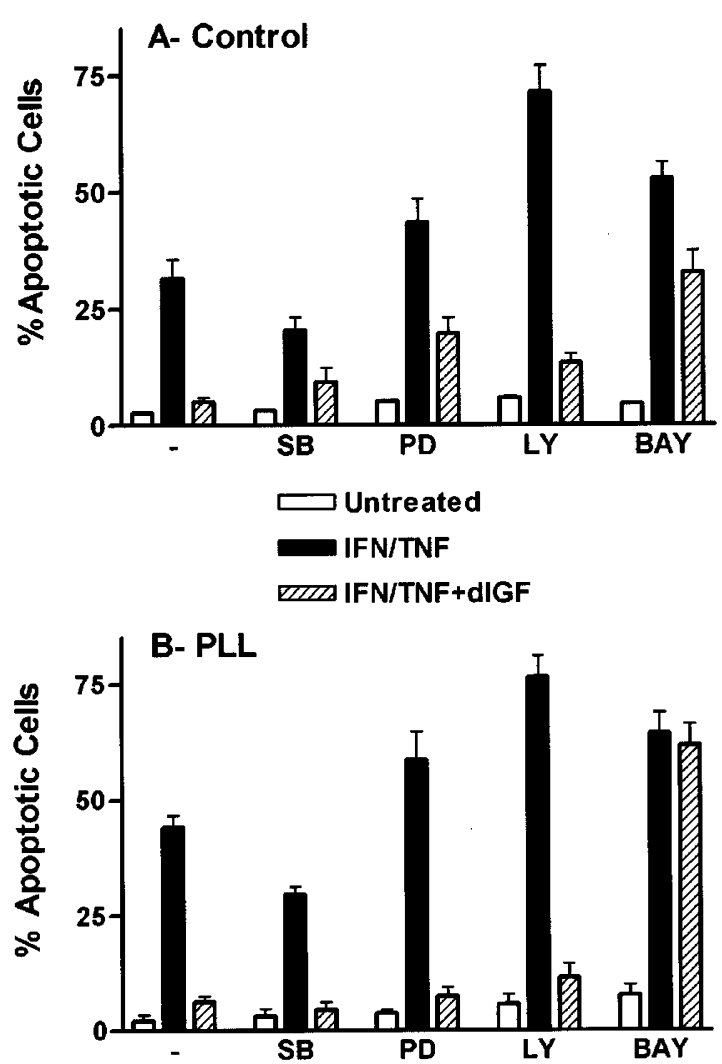

Figure 7 Effect of kinase inhibitors on the adhesion-independent antiapoptotic effect of IGF-I. HT29-D4 cells were plated on (A) $10 \%$ FCS, or (B) PLL-coated plates (PLL) for $16 \mathrm{~h}$, then either untreated $(-)$ or treated with the indicated pharmacological inhibitor as described in Materials and Methods. The cells were then left untreated (open bar) or 5-min pulse-treated with IFN $(40 \mathrm{ng} / \mathrm{ml})$, and then incubated for $24 \mathrm{~h}$ with TNF $(4.0 \mathrm{ng} / \mathrm{ml})$ in the absence (solid bar) or presence (hatched bar) of dIGF-I $(50 \mathrm{ng} / \mathrm{ml})$. Apoptotic cells in the culture were quantified by a flow cytometric assay as described in Materials and Methods. Concentrations of inhibitors were as follows: SB203580 (SB), $20 \mu \mathrm{M}$; PD098059 (PD), $100 \mu \mathrm{M}$; LY294002 (LY), $10 \mu \mathrm{M}$; BAY11-7082 (BAY), $50 \mu \mathrm{M}$. Values are the mean \pm S.D. from three independent experiments performed in duplicate totally suppressed the IGF-I protective effect against IFN/ TNF-induced apoptosis (Figure 7B).

Taken together, these data indicate that in the absence of cell-ECM interactions, IGF-I protects HT29-D4 cells from cytokine-induced apoptosis without using PI3K and MAPK (Erk and p38) pathways. In contrast, NF- $\kappa$ Bdependent signaling appears to be the major pathway used by IGF-I to exert its anti-apoptotic function.

Additional evidence that $\mathrm{NF}-\kappa \mathrm{B}$ is required for protection by IGF-I against IFN/TNF-induced apoptosis was obtained by using pharmacological inhibitors that interfere with different steps of the NF- $\kappa \mathrm{B}$ pathway. They comprised BAY11-7082 (see above), sodium salicylate $(20 \mathrm{mM})$ that has been reported to inhibit TNF-induced $\mathrm{I} \kappa \mathrm{B}$ phosphorylation, ${ }^{40}$ lactacystin $\beta$-lactone $(50 \mu \mathrm{M})$, a potent proteasome inhibitor preventing $\mathrm{I} \kappa \mathrm{B}$ degradation, ${ }^{41}$ and triptolide (PG490) (55 $\mathrm{nM})$ that inhibits the transcriptional activation of NF- $\kappa$ B. ${ }^{42}$ BAY11-7082 and triptolide did not alter the basal cell survival whereas sodium salicylate and lactacystin $\beta$-lactone induced a significant basal cell death (Figure 8, open bars). All these inhibitors induced a potent sensitization of HT29-D4 cells to killing by TNF alone, which contrasted with the control adherent cells that were totally resistant to TNF-induced apoptosis (Figure 8, shaded bars). ${ }^{23,29,30}$ However, it is important to note that inhibiting NF- $\kappa \mathrm{B}$ with any of the used inhibitors abrogated the anti-apoptotic effect of dIGF-I (Figure 8, hatched bars). The efficiency of the pharmacological inhibitors was verified prior to be used in the reported experiments. For PD098059, SB203580 and LY294002, this was done by

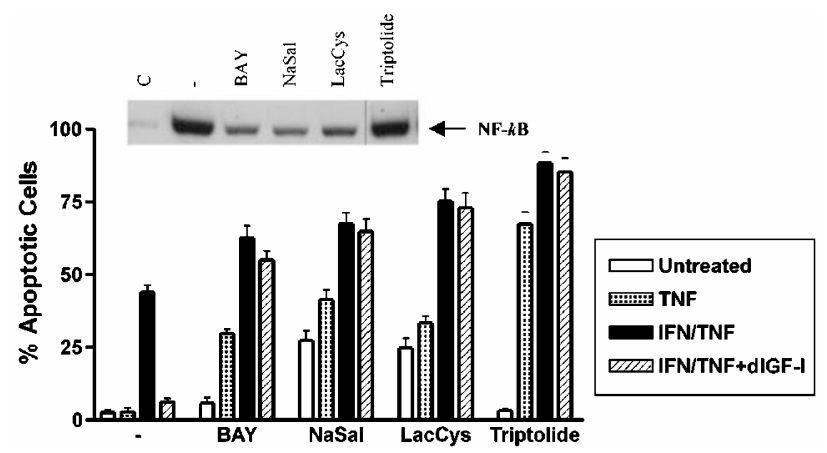

Figure 8 Pharmacological inhibitors of the NF- $k$ B pathway totally suppress the adhesion-independent anti-apoptotic effect of IGF-I. HT29-D4 cells were plated on PLL-coated plates for $16 \mathrm{~h}$, then either untreated $(-)$ or treated with the indicated pharmacological inhibitor as described in Materials and Methods. The cells were then left untreated (open bar), incubated with TNF $(4.0 \mathrm{ng} / \mathrm{ml})$ (shaded bar) or 5-min pulse-treated with IFN $(40 \mathrm{ng} / \mathrm{ml})$, and then incubated with TNF $(4.0 \mathrm{ng} / \mathrm{ml})$ in the absence (solid bar) or presence (hatched bar) of dIGF-I $(50 \mathrm{ng} / \mathrm{ml})$. After $24 \mathrm{~h}$ of incubation, apoptotic cells in the culture were quantified by a flow cytometric assay as described in Materials and Methods. Concentrations of inhibitors were as follows: BAY11-7082 (BAY), $50 \mu \mathrm{M}$; sodium salicylate (NaSal), $20 \mathrm{mM}$; lactacystin $\beta$-lactone (LacCys), $50 \mu \mathrm{M}$; triptolide, $55 \mathrm{nM}$. Values are the mean \pm S.D. from three independent experiments performed in duplicate. Insert: Efficiency of inhibitors to prevent the nuclear translocation of NF- $\kappa \mathrm{B}$ p65. Cells were either untreated throughout the experiment $(C)$ or preincubated without $(-)$ or with the indicated inhibitor, then treated with TNF $(4.0 \mathrm{ng} / \mathrm{ml})$ for $1 \mathrm{~h}$. Nuclear extracts were prepared as described in Materials and Methods and equal amounts of protein were analyzed for the presence of NF- $\kappa \mathrm{B}$ by Western blotting 
Western blot using Abs against the phosphorylated forms of Erk, p38 and Akt, respectively (not shown). For the inhibitors of NF- $\kappa$ B pathway, we verified that all suppressed $\mathrm{NF}-\kappa \mathrm{B}-$ dependent IL-8 production (not shown). In addition, BAY 11-7082, sodium salicylate and lactacystin $\beta$-lactone were found to prevent the TNF-induced nuclear NF- $\kappa \mathrm{B}$ expression (Figure 8, insert). Only triptolide did not, which agrees with its well known ability to inhibit transcriptional activation of NF- $\kappa$ B but not translocation to the nucleus and DNA binding of NF- $\kappa$ B. ${ }^{42}$

All these experiments thus indicate that in HT29-D4 cells cultured in the absence of cell-ECM interactions, (i) the resistance against TNF-induced apoptosis, and (ii) the IGFI-mediated resistance against the IFN/TNF-induced apoptosis, primary depend upon a functional NF- $\kappa \mathrm{B}$ signaling pathway.

\section{IGF-I Potentiates TNF- and IFN/TNF-induced NF- $\kappa$ B-dependent production of IL-8}

It has been demonstrated that $N F-\kappa B$ is critical in TNF mediation of IL-8 gene expression in HT29 cells. ${ }^{43}$ Here, we investigated at the protein level whether dIGF-I could stimulate IL-8 production in HT29-D4 cells. As previously reported, ${ }^{23}$ a weak constitutive production of $\mathrm{IL}-8$ was observed which was greatly enhanced ( $\sim 50$-fold) when the cells were stimulated with TNF (Figure 9). Although IFN did not potentiate IL-8 production by itself, IFN/TNF co-treatment induced a potent twofold stimulation of IL-8 production compared to the TNF-stimulated cells (Figure 9). Moreover, addition of dIGF-I induced a twofold stimulation of the basal, TNF- and IFN/TNF-induced IL-8 production, and this ability was the same whether the cells were cultured in standard conditions or plated on PLL (Figure 9). Moreover, the

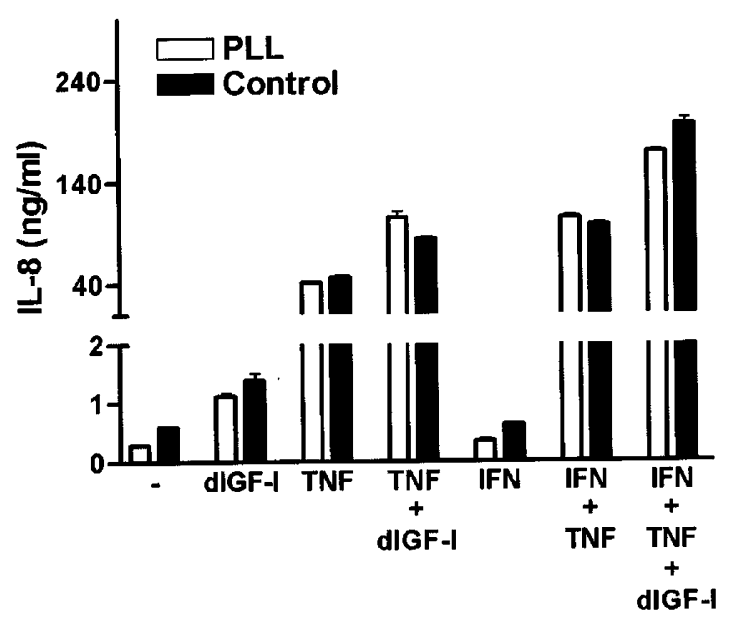

Figure 9 Synergistic activation of the NF- $\kappa$ B-dependent production of IL-8 by TNF/IGF-I or TNF/IFN is independent on cell interactions with ECM. HT29-D4 cells were plated for $5 \mathrm{~h}$ on either $10 \%$ FCS- (Control; solid bar) or PLL- (open bar) coated plates. Cells were either pulse treated for 5-min with IFN (40 ng/ $\mathrm{ml}$ ) (IFN) or not, then incubated with TNF $(4.0 \mathrm{ng} / \mathrm{ml})$ (TNF) with or without dIGF-I (50 ng/ml) (dIGF-I). Supernatants were harvested after $24 \mathrm{~h}$, cell debris was discarded, and IL-8 was measured by enzyme immunoassay. Values are the mean $\pm S D$ from five independent experiments performed in triplicate presence of anti-E-cadherin MB-2 mAb did not alter this IGF-I capability (not shown).

These data clearly indicate that IGF-I functions in cooperation with TNF and IFN to synergistically activate the NF- $\kappa$ B-dependent production of IL-8 whether HT29-D4 cells interact or not with ECM or neighboring cells.

\section{Discussion}

We have previously reported that IGFs and insulin induce an almost complete cell resistance against apoptosis mediated by TNF in IFN-sensitized HT29-D4 human colon carcinoma cells. ${ }^{23}$ In this study, we show that these peptides mediate the same strong protective effect when the cells are cultured under conditions in which cell-ECM and cell-cell interactions are abolished. Thus, the IGF-I/insulin anti-apoptotic signaling is independent of integrin- and E-cadherin-mediated signaling pathways. Such a result is noticeable because the activation of signaling pathways from adhesion molecules is generally required for a full activation of the IGF-IR-dependent biological responses. ${ }^{24,25}$ This is also true in the HT29-D4 cell system where integrins and E-cadherin cooperate with IGF-I to promote cell migration. ${ }^{26}$ As the crosstalk with adhesion molecules is not required, IGF-I is able to render colon cancer cells resistant to apoptosis whatever their anchorage dependence, which is extremely deleterious because promoting metastasis. In the absence of cell adhesion, IGF-I can still activate the well-established MAPK (Erk-1 and -2, and p38) and PI3K/Akt anti-apoptotic pathways. However, we show that the key determinant for IGF-I to deliver an efficient protective signal is the enhancement of the TNF-induced NF$\kappa \mathrm{B}$ activity.

The adherence-independent anti-apoptotic effect of IGF-I has been investigated by seeding the cells in SFM on different specific ECM ligands to test the engagement of specific integrins, and on two types of substrata that deny the cells interaction with the ECM: (i) PLL, which prevents integrin engagement $^{27}$ and, (ii) poly-HEMA, which allows suspension culture conditions. ${ }^{28}$ HT29-D4 cells cultured in suspension formed compact multicellular aggregates mediated by E-cadherin. Such E-cadherin-mediated intercellular interactions have been reported to be involved in anchorage-independent survival. ${ }^{12}$ Therefore, the IGF-I anti-apoptotic effect was also assayed in the presence of function-blocking antibodies: (i) the MB-2 mAb against Ecadherin which prevents the cell-cell interactions and formation of multicellular aggregates; (ii) a mixture of mAbs against $\alpha_{v}, \alpha_{6}$ and $\beta_{1}$ integrin subunits, which recovers the pattern of HT29-D4 cell-expressed integrins. ${ }^{27}$ The addition of these mAbs to cells cultured in independence of ECM did not alter their resistance to IFN/TNF-mediated cell death in response to IGF-I. This observation argues that neither integrins nor E-cadherin participate in the IGF-I antiapoptotic effect.

To avoid any misunderstanding, we would like to emphasize that such a conclusion does not presume that the signals issued from adhesion molecules are in no way involved in the cell survival. For instance, the loss of the ability to form dense multicellular aggregates in the presence of anti-E-cadherin mAb induced HT29-D4 cell 
death through apoptosis after $\sim 5$ days of culture in suspension (data not shown). This is, however, significantly longer than the period of the assay performed here to measure IFN/TNF-induced apoptosis i.e., $24 \mathrm{~h}$. We also observed that the extent of IFN/TNF-induced apoptosis was increased when the cells were cultured in the absence of interactions with ECM. The adhesion to ECM thus contributes at least in part in the HT29-D4 cell resistance against cytokine-induced apoptosis. However, the ECMdependent signaling is dispensable for HT29-D4 cell survival since these cells were able to survive and to grow in suspension for at least 15 days (unpublished observation). Such an ability to resist to cell-detachment-induced apoptosis, referred as loss of anoikis, is a property frequently associated to cell transformation. ${ }^{11,32}$ In HT29D4 cells, it may be related to the known activation of oncogenes, e.g., ras, and inactivation of tumor-suppressor genes, e.g., $A P C$ and $p 53$, which have been reported to be involved in the control of anoikis.

To analyze the mechanisms by which IGF-I functions as an adhesion-independent anti-apoptotic factor, we first assessed the efficiency of the IGF-I signal transduction in HT29-D4 cells cultured in independence of cell-ECM (on PLL-coated plates) and cell-cell (in the presence of anti-Ecadherin $\mathrm{mAb}$ ) interactions. Since regulation of IGF-I and insulin signaling by cell adhesion molecules can intervene at different levels of signal propagation, both proximal and distal signaling events have been assayed. In HT29-D4 cells, the number of IGF-IR ( $\sim 30000 /$ cell) and insulin receptor (IR) $\left(\sim 5000 /\right.$ cell) is not overexpressed, ${ }^{44}$ and the adherence-independent anti-apoptotic effect of IGF-I and insulin was obtained for physiological concentrations of each one of these peptides $\left(\mathrm{IC}_{50}\right.$ of 0.15 and $0.55 \mathrm{nM}$, respectively). This suggests that IGF-I and insulin protect the cells via their cognate receptors which agrees with our previous findings with HT29-D4 cells cultured under standard conditions. ${ }^{23}$ With the exception of FAK, the tyrosine phosphorylation of which was found to require cell contact with ECM, the main signaling pathways downstream of the IGF-IR, i.e., IRS-1, MAPK (Erk 1 and 2, p38) and PI3K/Akt, were activated by IGF-I in a similar manner whether HT29-D4 cells were cultured under standard or adhesion-independent conditions. Thus, our data support the conclusion that IGF-I can efficiently signal in HT29-D4 cells whether integrin and E-cadherin receptors are activated or not.

Such a conclusion may, however, appear surprising since increasing evidence shows that many cell functions require a collaboration between the adhesion molecules and growth factors. ${ }^{24,25}$ For instance, the survival function of insulin in primary mammary epithelial cells has been reported to be dependent on ECM. ${ }^{45}$ In the HT29-D4 cell model, we also reported that the IGF-I-induced cell migration $^{22}$ requires an interplay between IGF-IR, integrins and E-cadherin/catenin complexes. ${ }^{26}$ However, Valentinis et al. $^{46}$ have demonstrated that IGF-I, which can rescue mouse embryo fibroblasts from anoikis, induced the activation of PI3K/Akt and MAPK pathways regardless of whether these activities were measured in cell monolayers or cells kept in suspension. This latter observation is in complete agreement with our current findings. The discrepancies noted in the literature may be largely due to the different cell types (e.g., primary normal epithelial cells vs cancer cell lines) and experimental procedures (e.g., shortvs long-term treatments; trypsin- vs EDTA-induced cell detachment) used. In our experiments, cells were detached by EDTA, since trypsinization is known to partially digest the extracellular portions of growth factor receptors, ${ }^{47}$ which may explain why some signals are abrogated following removal from ECM. Finally, whether the efficiency of the adherence-independent IGF-I anti-apoptotic signaling can be extended to a wide spectrum of cancer cells remains to be established.

We have also obtained with the HT29-D4 cell model some interesting indications about the signaling pathways used by the IGF-IR to exert its anti-apoptotic effect independently of the cellular adhesion molecules. Overall our studies show a lack of correlation with the signaling pathways that have been reported to play an important role in protection from apoptosis in general, and in IGF-IRmediated survival in particular.

First, it seemed reasonable to study the relationship between the activated IGF-IR and FAK phosphorylation because activation of FAK has been widely shown to be crucial for transducing survival signals from integrinmediated cell-ECM interactions. ${ }^{11,32}$ In addition, insulin and IGF-I have been reported in several cell systems to modulate FAK tyrosine phosphorylation and activation, and cell adhesion appears to control this effect. ${ }^{48}$ In agreement with these observations, we observed that FAK was tyrosine phosphorylated in HT29-D4 cells cultured in standard conditions. Moreover, IGF-I was able to increase the extent of this phosphorylation. As expected, FAK was not phosphorylated in cells seeded on PLL- or poly-HEMAcoated plates. We hypothesized that the ability of IGF-I to deliver its anti-apoptotic effect in non-adherent cells might be due to its ability to induce FAK phosphorylation. However, when the cells were cultured in ECM-independence conditions, we could not detect any effect of IGF-I on FAK phosphorylation. Thus, we conclude that activation of FAK is not used by IGF-I as a primary survival pathway. A similar conclusion has been reported by Valentinis et al. ${ }^{49}$ in their study about the ability of IGF-I to protect embryonic fibroblasts from anoikis.

The same lack of correlation with the IGF-I anti-apoptotic effect has been observed for the PI3K/Akt signaling pathway. An abundance of studies indicate that PI3K, which in turn activates its immediate downstream target $\mathrm{Akt}^{34,35}$ is the main pathway for the anti-apoptotic effect of IGF-I in several cell systems. ${ }^{14,16,50,51}$ Although PI3K and Akt phosphorylation was markedly increased in HT29-D4 cells after IGF-I stimulation, we observed that LY294002, a specific inhibitor of PI3K activity, ${ }^{38}$ did not at all affect the protective effect of IGF-I regardless of whether cells were cultured under adhesion-dependent conditions or not. We have also used wortmannin as a PI3K inhibitor with the same results. Thus, whatever the adherence status of HT29-D4 cells, activation of the canonical PI3K/Akt antiapoptotic pathway is not an absolute requirement for IGF-I to induce resistance against IFN/TNF-induced apoptosis. 
Of interest, several investigators have now noticed that the anti-apoptotic activity of IGF-I does not always correlate with the activation of PI3K/Akt activities in other cell systems. $^{16,51}$

HT29-D4 cells exhibited a constitutive activation of Erk-1 and -2 MAPK, which has been observed in a relatively large number of human colon tumors. ${ }^{33}$ We show here that Erk-1, -2, and p38 MAPK were further activated by IGF-I regardless of whether the cells were cultured in contact with ECM or not. Thus, we hypothesized that activation of MAPK cascades might be an alternative IGF-IR-mediated anti-apoptotic pathway because such a function has been previously reported in other cell systems. ${ }^{16,50}$ In ECMattached cells, we indeed observed that PD098059 and SB203580 reversed by $\sim 40 \%$ the anti-apoptotic effect of IGF-I, which indicates that Erk and p38 MAPK convey a part of the IGF-I protective effect. This result is in agreement with our previously reported experiments. ${ }^{23}$ However, in the absence of ECM-cell interaction, the addition of PD098059 and SB203580 did not affect at all the IGF-I-mediated anti-apoptotic effect. Thus, the IGF-IR can protect ECM-independent cells against IFN/TNFinduced apoptosis by a mechanism that does not require MAPK activation.

Recently, it has been shown that NF- $\kappa \mathrm{B}$ activation was responsible for the resistance against apoptosis induced by TNF, and a variety of other proapoptotic stimuli in many types of cells. ${ }^{52,53}$ More specifically, TNF can generate two types of signal, one that induces apoptosis by recruiting and activating adaptator proteins, such as Fas-associated protein with death domain (FADD), and pro-caspase 8 , and another that activates NF- $\kappa \mathrm{B}$ and protects against cell death. 2,8,9 These two pathways are working against each other in a delicate balance from which will depend the lifeor-death cell's decision. Therefore, an interesting finding of our study is that the adhesion-independent IGF-I antiapoptotic effect requires the activation of $\mathrm{NF}-\kappa \mathrm{B}$, because inhibition of this pathway totally prevented the protection by IGF-I of IFN/TNF-induced apoptosis. This prevention was observed whatever the level at which the NF- $\kappa$ B block was done: $I_{\kappa} \mathrm{B}$ phosphorylation (BAY11-7082, NaSal), $\left.\right|_{\kappa} \mathrm{B}$ degradation (lactacystin) or NF- $\kappa \mathrm{B}$ transactivation (triptolide). Thus, NF- $\kappa \mathrm{B}$ appears to be an alternative pathway to MAPK and PI3K/Akt signaling for the IGF-IR-mediated protection against apoptosis in colon cancer cells. NF- $\kappa \mathrm{B}$ has been shown to exert its anti-apoptotic effect via the synthesis of several anti-apoptotic proteins, ${ }^{54}$ which is also in agreement with the protein synthesis dependence we reported for the IGF-I anti-apoptotic effect. ${ }^{23}$ Additionally, the neuroprotection mediated by IGF-I against oxidative stress $^{55}$ and the anti-apoptotic function of insulin in IRoverexpressing $\mathrm{CHO}$ cells ${ }^{15}$ have also been shown to require $\mathrm{NF}-\kappa \mathrm{B}$ activity. Confirmation that the NF- $\kappa \mathrm{B}$ pathway is a key target for IGF-I signaling comes from our experiments measuring in HT29-D4 cells the production of IL-8, a NF- $\kappa$ B-dependent pro-inflammatory cytokine. ${ }^{43}$ IGF-I did significantly activate the constitutive IL-8 production, and strongly potentiate the TNF- and IFN/TNF-induced IL-8 production regardless of whether cell-cell and cell-ECM interactions were neutralized or not. Thus, enhancement of the TNF-induced NF- $\kappa \mathrm{B}$ activation appears to be the main, if not the only, pathway by which IGF-I allows to adhesionindependent HT29-D4 cells to resist to IFN/TNF-mediated cell death. In addition, the NF- $\kappa \mathrm{B}$ activation status seems to have a wider impact on the survival of colon carcinoma cells since blocking NF- $\kappa \mathrm{B}$ signaling dramatically sensitized the cells to TNF-mediated apoptosis. Thus, our results indicate that NF- $\kappa \mathrm{B}$ is a key determinant to control both survival and resistance to apoptosis in colon cancer cells.

With regard to this conclusion, the observed ambivalent function of IFN in HT29-D4 cells is of particular interest: on the one hand, the sensitization of the cells by IFN is an absolute requirement for triggering HT29-D4 cell apoptosis in response to $\mathrm{TNF}^{23}$ on the other hand IFN strongly enhances the TNF-induced NF- $\kappa$ B-dependent IL-8 production (IFN by itself did not significantly enhance the basal IL8 secretion). Cheshire and Baldwin ${ }^{56}$ have also reported that IFN can strongly potentiate the ability of TNF to induce $\mathrm{NF}-\kappa \mathrm{B}$ activation. Thus, our data indicate that whether enhancement of TNF-induced activation of NF- $\kappa B$ is linked to a pro-apoptotic or survival signaling depends on the stimulus causing this enhancement, e.g., IFN, IGF-I or both simultaneously. This observation may be linked to the proapoptotic role of NF- $\kappa \mathrm{B}$ in neuronal cells, ${ }^{54}$ and also in HT29 cells. ${ }^{57}$ We do not yet know how TNF/IFN and TNF/ IFN/IGF-I co-treatments lead to enhanced activation of NF$\kappa \mathrm{B}$ whereas they induce pro- and anti-apoptotic responses, respectively. Although further work is obviously needed, we would like to suggest that the stimulation of NF- $\kappa$ B by TNF in the presence of IFN with or without IGF-I may differentially induce the expression of the Rel/NF- $\kappa \mathrm{B}$ family of proteins, modulate their interactions with transcriptional co-activators and/or differentially regulate the expression of genes that co-operate with NF- $\kappa \mathrm{B}$ to control cell death. In addition, since the activation of $\mathrm{NF}-\kappa \mathrm{B}$ is involved not only in the anti-apoptotic but also in the pro-inflammatory responses of intestinal epithelial cells, ${ }^{58}$ it might be suggested that these two biological functions are linked.

In conclusion, we summarize our data as follows: (i) IGFI can protect HT29-D4 cells from IFN/TNF-induced apoptosis, and this does not need an interplay with survival signals transmitted from E-cadherin and integrin receptors; (ii) the activation by IGF-I of several of the previously reported consensus pathways, especially IRS-1, PI3K/Akt, p38, and Erk 1 and 2 MAPK is adhesion-independent in HT29-D4 cells; (iii) in these conditions, these canonical survival pathways do not convey the IGF-I anti-apoptotic message; and finally, (iv) an alternative survival pathway for IGF-I is linked to its ability to enhance the IFN/TNFmediated activation of the NF- $\kappa$ B pathway.

These findings may have important biological and clinical implications because they support the notion that the IGF axis (peptides, receptors and IGF binding proteins) may constitute a major therapeutic target for combating colon cancer. Because the deleterious capabilities of the IGF system to support aberrant cell survival are also operating in cancer cells that detach from ECM, they should contribute to the limited efficiency of conventional as well as immune-mediated anti-cancer therapies, especially during the life-threatening process of metastasis. 


\section{Materials and Methods}

\section{Cell culture}

The HT29-D4 human colon carcinoma cell line was cultured routinely in Dulbecco's modified Eagle medium (DMEM) (Life Technologies, Grand Island, NY, USA) supplemented with 10\% FCS (Life Technologies) as reported elsewhere. ${ }^{21}$

For these studies, tissue culture plastic wells were coated overnight at $4^{\circ} \mathrm{C}$ with $10 \mu \mathrm{g} / \mathrm{ml}$ of type IV collagen (Sigma, L'Isle d'Abeau, France), vitronectin (prepared as described previously), ${ }^{27}$ $30 \mu \mathrm{g} / \mathrm{ml}$ of fibronectin (Sigma), laminin-1 (prepared as described previously), ${ }^{27}$ or $10 \mu \mathrm{g} / \mathrm{ml}$ of PLL (Sigma). For suspension cultures, tissue culture wells were coated with poly-(2-hydroxyethyl methacrylate) (poly-HEMA) (Sigma) following the protocol reported by Folkman and Moscona. ${ }^{28}$ Briefly, a solution of $10 \mathrm{mg} / \mathrm{ml}$ of poly-HEMA in $95 \%$ ethanol was applied onto the dishes $\left(0.95 \mu \mathrm{l} / \mathrm{mm}^{2}\right)$, drying in the tissue culture hood and repeating once. For control cultures, wells were coated in the same conditions with DMEM containing 10\% FCS. Just before plating cells, the coated wells were washed twice with phosphate-buffered saline (PBS) containing $1 \%$ bovine serum albumin (BSA) (Sigma), and once in SFM, i.e., DMEM containing $0.1 \%$ BSA.

HT29-D4 cells were first plated on regular culture flasks at $2 \times 10^{5}$ cells $/ \mathrm{cm}^{2}$ for $24 \mathrm{~h}$ and then a single cell suspension was obtained by using $0.53 \mathrm{mM}$ EDTA only. After washing with PBS, cells were plated on coated wells at about $2 \times 10^{5}$ cells $/ \mathrm{cm}^{2}$ in SFM with or without $1.0 \mu \mathrm{g} / \mathrm{ml}$ of anti-E-cadherin MB-2 monoclonal antibody (mAb) (a gift from Dr. M Mareel, Gent, Belgium) or a mixture of mAbs $(1.0 \mu \mathrm{g} / \mathrm{ml}$ each) against integrin subunits: $\alpha_{v}(69.6 .5),{ }^{59} \alpha_{6}(\mathrm{GoH} 3)$ and $\beta_{1}$ (Lia1/ 2) (Beckman/Immunotech, Marseille, France). After 5 or 16 h of culture (as outlined under the figures), induction of apoptosis was done as described below.

\section{Apoptosis assay}

Cells plated on the variously coated wells were washed with and incubated in SFM with $40 \mathrm{ng} / \mathrm{ml} \mathrm{IFN} \mathrm{(R \& D} \mathrm{Systems,} \mathrm{Oxon,} \mathrm{UK)} \mathrm{for}$ $5.0 \mathrm{~min}$ at $37^{\circ} \mathrm{C}$, then washed twice, and apoptosis was triggered in SFM by adding $4.0 \mathrm{ng} / \mathrm{ml}$ TNF (R\&D Systems) in the presence or absence of $50 \mathrm{ng} / \mathrm{ml}$ bovine insulin (Sigma) or dIGF-I (GroPep, Adelaide, Australia). Whenever used, mAbs to anti-integrin subunits or anti-E-cadherin were added again at the same concentrations as those reported in the preceding paragraph and maintained throughout the experiment. Pharmacological inhibitors (PD098059, LY294002, SB203580 from Alexis Biochemicals, San Diego, CA, USA; sodium salicylate (NaSal) from Sigma; BAY11-7082, lactacystin $\beta$ lactone, triptolide from BioMol, Plymouth Meeting, PA, USA) were added to the cells $2 \mathrm{~h}$ ( $5 \mathrm{~h}$ for triptolide) prior to the induction of apoptosis. After a $24 \mathrm{~h}$ period of incubation, non-adherent and adherent cells (recovered by $0.05 \%$ trypsin and $0.53 \mathrm{mM}$ EDTA) were combined and the apoptotic cell population was determined by a flow cytometric assay. ${ }^{60}$ Briefly, $1 \times 10^{6}$ cells $/ \mathrm{ml}$ were treated by an hypotonic fluorochrome solution containing $0.1 \%$ Triton $\mathrm{X}-100,0.1 \%$ sodium citrate, and $50 \mu \mathrm{g} /$ $\mathrm{ml}$ propidium iodide $(\mathrm{PI})$. Flow cytometric analyses were done on a FacSort (Becton Dickinson, San Jose, CA, USA) for quantifying the proportion of hypodiploid nuclei (pre- $\mathrm{G}_{1}$ peak). Ten thousand events were examined for each determination, and the data were analyzed using the Cell Quest software package (Becton Dickinson). All the experiments were made in duplicate and repeated at least three times.

\section{Immunoprecipitation and Western blot analysis}

Cells were either untreated or treated with $50 \mathrm{ng} / \mathrm{ml}$ dIGF-I for different times at $37^{\circ} \mathrm{C}$, then rapidly washed with ice-cold PBS and lysed with
$20 \mathrm{mM}$ Tris- $\mathrm{HCl}$ (pH 8.0), $200 \mathrm{mM} \mathrm{NaCl}, 1 \mathrm{mM}$ EDTA and 1.0\% Triton X-100 (RIPA buffer) containing $10 \mathrm{mM}$ sodium orthovanadate, $10 \mathrm{mM}$ sodium pyrophosphate, $10 \mathrm{mM} \mathrm{NaF}$ and a mixture of protease inhibitors (aprotinin, leupeptin, iodoacetamin, and pepstatin, $1.0 \mu \mathrm{g} /$ $\mathrm{ml}$ each) and $1 \mathrm{mM}$ phenylmethylsulfonylfluoride. Cell lysates containing equal amounts of protein were incubated with 1-2 $\mu \mathrm{g}$ of $\mathrm{Ab}$ overnight at $4.0^{\circ} \mathrm{C}$, and then with protein $\mathrm{G}$-agarose beads (Boehringer-Mannheim, Mannheim, Germany) for $45 \mathrm{~min}$. Pellets were washed three times with the RIPA buffer, three times with RIPA buffer containing $500 \mathrm{mM} \mathrm{NaCl}$ and once with PBS. The disrupted monolayer was extensively washed with buffer lacking Triton X-100 to remove contaminating cytosol proteins. Nuclear extracts were prepared by adding ice-cold buffer consisting of $50 \mathrm{mM}$ HEPES, $\mathrm{pH} 7.8,10 \% \mathrm{v} / \mathrm{v}$ glycerol, $50 \mathrm{mM} \mathrm{KCl}, 300 \mathrm{mM} \mathrm{NaCl}, 1 \mathrm{mM}$ dithiothreitol, and $0.1 \mathrm{mM}$ EDTA supplemented with the above indicated protease inhibitors. Immunoprecipitated proteins, nuclear extracts or whole cell lysates were subjected to sodium dodecyl sulfate-polyacrylamide gel electrophoresis (SDS-PAGE), then transferred onto nitrocellulose sheets (Hybond-C extra, Amersham, Aylesbury, UK), and probed with Abs to phosphotyrosine (PY99; $0.05 \mu \mathrm{g} / \mathrm{ml})$, IRS-1 (H-165; $0.4 \mu \mathrm{g} / \mathrm{ml})$, FAK (C-20; $0.2 \mu \mathrm{g} / \mathrm{ml})$, Erk (K-23; $0.4 \mu \mathrm{g} / \mathrm{ml})$, p38 (C-20; $0.4 \mu \mathrm{g} / \mathrm{ml})$, PI3K p85 $\alpha$ (Z-8; $2 \mu \mathrm{g} / \mathrm{ml})$, NF- $\kappa$ B p65 (C-20; $0.2 \mu \mathrm{g} / \mathrm{ml})$ (all from Santa Cruz Biotechnology, Santa Cruz, CA, USA), phospho-Erk (1:1000), phospho-p38 (1:1000), phospho-Akt $(1: 1000)$, Akt $(1: 1000)$ (all from New England BioLabs, Beverly, MA, USA). In each of the studies presented, the results shown are typical of at least three independent experiments. Autoradiographs were quantitated by scanning densitometry and absorbances curves integrated using the ImageMaster software (Pharmacia Biotech, St Quentin-Yvelines, France). Densitometric analyses were performed on gels with exposure times giving linear absorbance curves.

\section{IL-8 assay}

IL-8 concentration in SFM conditioned by untreated or dIGF-I-treated cells was determined using a commercially available enzyme immunoassay kit, according to the manufacturer's instructions (Diaclone, Besançon, France).

\section{Statistical methods}

The data were analyzed using the Statview software package (Abacus, Berkeley, CA, USA). Results were expressed as the mean \pm S.D. of triplicate determinations. Significant effects were determined using the nonparametric Mann-Whitney test. A statistically significant difference was considered to be present at $P<0.05$.

\section{Acknowledgements}

The authors thank Roselyne Rance for excellent technical assistance, Charles Prevot for carrying the flow cytometric analyses, and Dr. M Mareel (Gent, Belgium) for kindly providing the MB-2 antibody to Ecadherin. The help of Dr. Christine Beeton in the preparation of the manuscript is gratefully acknowledged.

\section{References}

1. Potten CS (1997) Epithelial cell growth and differentiation. II. Intestinal apoptosis. Am. J. Physiol. 273: G253-G257

2. Ashkenazi A and Dixit V (1998) Death receptors: signaling and modulation. Science 281: $1305-1308$ 
3. Krammer PH (2000) CD95's deadly mission in the immune system. Nature 407: 789-795

4. Shresta S, Pham CTN, Thomas DA, Graubert TA and Ley TJ (1998) How do cytotoxic lymphocytes kill their targets? Curr. Opin. Immunol. 10: 581-587

5. Micheau O, Solary O, Hammann A, Martin F and Dimanche-Boitrel MT (1997) Sensitization of cancer cells treated with cytotoxic drugs to Fas-mediated cytotoxicity. J. Natl. Cancer Inst. 89: 783-789

6. Thompson CB (1995) Apoptosis in the pathogenesis and treatment of disease. Science 267: $1456-1462$

7. Reed JC (1999) Dysregulation of apoptosis in cancer. J. Clin. Oncol. 17: $2941-$ 2953

8. Hengartner MO (2000) The biochemistry of apoptosis. Nature 407: 770-776

9. Green DR (1998) Apoptotic pathways: the roads to ruin. Cell 94: 695-698

10. Raff MC (1992) Social control on cell survival and cell death. Nature 356: 397 400

11. Frish SM and Francis $H$ (1994) Disruption of epithelial cell-matrix interactions induces apoptosis. J. Cell. Biol. 124: 619-626

12. Kantak SS and Kramer RH (1998) E-cadherin regulates anchorageindependence growth and survival in oral squamous cell carcinoma cells. J. Biol. Chem. 273: 16953-16961

13. Butt AJ, Firth SM and BaxterRC (1999) The IGF axis and programmed cell death Immunol. Cell. Biol. 77: 256-262

14. Baserga R, Hongo A, Rubini M, Prisco M and Valentinis B (1997) The IGFreceptor in cell growth, transformation and apoptosis. Biochim. Biophys. Acta. 1332: F105-F126

15. Bertrand F, Atfi A, Cadoret A, L'Allemain G, Robin H, Lascols O, Capeau J and Cherqui $\mathrm{G}$ (1998) A role for nuclear factor $\kappa B$ in the antiapoptotic function of insulin. J. Biol. Chem. 273: 2931-2938

16. Peruzzi F, Prisco M, Dews M, Salomoni P, Grassilli E, Romano G, Calabretta B and Baserga R (1999) Multiple signaling pathways of the insulin-like growth factor 1 receptor in protection from apoptosis. Mol. Cell. Biol. 19: 7203-7215

17. Read LC, Lemmey AB, Howarth GS, Martin AA, Thomas FM and Ballard FJ (1991) The gastrointestinal tract is one of the most responsive target tissues for IGF-I and its potent analogs. In Modern Concepts of insulin-like growth factors, Spencer EM, ed. (New York: Elsevier Science) pp. 225-234

18. Singh $P$ and Rubin N (1993) Insulinlike growth factors and binding proteins in colon cancer. Gastroenterology 105: 1218-1237

19. Baciuchka M, Remacle-Bonnet M, Garrouste F, Fabre R, Sastre B and Pommie G (1998) Insulin-like growth factor (IGF)-binding protein-3 (IGFBP-3)proteolysis in patients with colorectal cancer: possible association with the metastatic potential of the tumor. Int. J. Cancer 79: 460-467

20. Ma J, Pollak M, Giovannucci E, Chan J, Tao Y, Hennekens $\mathrm{CH}$ and Stampfer MJ (1999) Prospective study of colorectal risk in men and plasma levels of insulinlike growth factor (IGF)-I and IGF binding protein-3. J. Natl. Cancer Inst. 91:620625

21. Remacle-Bonnet M, Garrouste F, El Atiq F, Roccabianca M, Marvaldi J and Pommier G (1992) Des-(1-3)-IGF-I, an insulin-like growth factor analog used to mimic a potential autocrine loop, promotes the differentiation of human coloncarcinoma cells. Int. J. Cancer 52: 910-917

22. André F, Rigot V, Remacle-Bonnet M, Luis J, Pommier G and Marvaldi J (1999) Protein kinases $\mathrm{C}-\gamma$ and $-\delta$ are involved in insulin-like growth factor l-induced migration of colonic epithelial cells. Gastroenterology 116: 64-77

23. Remacle-Bonnet MM, Garrouste FL, HellerS, André F, Marvaldi JL and Pommier GJ (2000) Insulin-like growth factor-I protects colon cancer cells from death factor-induced apoptosis by potentiating tumor necrosis factor $\alpha$-induced mitogen-activated protein kinase and nuclear factor $\kappa \mathrm{B}$ signaling pathways. Cancer Res. 60: 2007-2017

24. Schwartz M and Baron V (1999) Interactions between mitogenic stimuli, or, a thousand and one connections. Curr. Opin. Cell Biol. 11: 197-202

25. Lee Y-Ja and Streuli CH (1999) Extracellular matrix selectively modulates the response of mammary epithelial cells to different soluble signaling ligands. J. Biol. Chem. 274: 22401-22408

26. André F, RigotV, Thimonier J, Montixi C, ParatF, Pommier G, Marvaldi Jand Luis $\mathrm{J}(1999)$ Integrins and E-cadherin cooperate with IGF-I to induce migration of epithelial colonic cells. Int. J. Cancer 83: 497-505

27. Rigot V, Lehmann M, André F, Daemi N, Marvaldi J and Luis J (1998) Integrin ligation and $\mathrm{PKC}$ activation are required for migration of colon carcinoma cells. J. Cell Science 111: 3119-3127
28. Folkman J and Moscona A (1978) The role of cell shape in growth control. Nature 273: $345-349$

29. Von Reyher U, Sträter J, Kittstein W, Gschwendt M, Krammer PH and Möller P (1998) Colon carcinoma cells use different mechanisms to escape CD95mediated apoptosis. Cancer Res. 58: 526-534

30. Ossina NK, Cannas A, Powers VC, Fitzpatrick PA, Knight JD, Gilbert JR, Shekhtman L, Tomei D, Umansky SR and Kiefer MC (1997) Interferon- $\gamma$ modulates a p53-independent apoptotic pathway and apoptosis-related gene expression. J. Biol. Chem. 272: 16351-16357

31. Blakesley VA, Butler AA, Koval AP, Okubo Y and LeRoith D. IGF-I receptor function: transducing the IGF-I signal into intracellular events (1999) In The IGF System, Rosenfeld RG and Roberts CT, eds. (Totowa: Humana Press) pp. 143163

32. Frisch S and Ruoslahti E (1997) Integrins and anoikis. Curr. Opin. Cell. Biol. 9: $701-706$

33. Hoshino R, ChataniY, Yamori T, Tsuruo T, OkaH, Yoshida O, Shimada Y, Ari-iS, Wada H, Fujimoto J and Kohno M(1999) Constitutive activation of the $41-/ 43-\mathrm{kDa}$ mitogen-activated protein kinase signaling pathway in human tumors. Oncogene 18: $813-822$

34. Downward $\mathrm{J}$ (1998) Mechanisms and consequences of activation of protein kinase B/Akt. Curr. Opin. Cell. Biol. 10: 262-267

35. Franke TF, Kaplan DR and Cantley LC (1997) PI3K: downstream AKTion blocks apoptosis. Cell 88: $435-437$

36. Alessi DR, Cuenda A, Cohen P, Dudley DT and Saltiel AR (1995) PD98059 is a specific inhibitor of the activation of the mitogen-activated protein kinase-kinase in vitro and in vivo. J. Biol. Chem. 270: 27489-27494

37. Cuenda A, Rouse J, Doza YN, Meier R, Cohen P, Gallagher TF, Young PR and Lee JC (1995) SB203580 is a specific inhibitor of a MAP kinase homologue which is stimulated by cellular stresses and interleukin-1. FEBS Lett. 364: 229-233

38. Vlahos CJ, Matter WF, Hui KY and Brown RF (1994) A specific inhibitor of phosphatidylinositol 3-kinase, 2-(4-morpholinyl)-8-phenyl-4H-1-benzopyran-4one (LY294002). J. Biol. Chem. 269: 5241-5248

39. Pierce JW, Schoenleber R, Jesmok G, Best J, Moore SA, Collins T and Gerritsen ME (1997) Novel inhibitors of cytokine-induced $\mathrm{I}_{\kappa} \mathrm{B} \alpha$ phosphorylation and endothelial cell adhesion molecule expression show anti-inflammatory effects in vivo. J. Biol. Chem. 272: 21096-21103

40. SchwengerP, AlpertD, SkolnikEY and VilcekJ (1998)Activation of p38 mitogenactivated protein kinase by sodium salicylate leads to inhibition of tumor necrosis factor-induced $I_{\kappa} B \alpha$ phosphorylation and degradation. Mol. Cell Biol. 18: 78-84

41. Craiu A, Gaczynska M, Akopian T, Gramm CF, Fenteany G, Goldberg AL and Rock KL (1997) Lactacystin and clasto-lactacystin $\beta$-lactone modify multiple proteasome $\beta$-subunits and inhibit intracellular protein degradation and major histocompatibility complex class I antigen presentation. J. Biol. Chem. 272: $13437-13445$

42. Lee KY, Chang W, Qiu D, Kao PN and Rosen GD (1999) PG490 (triptolide) cooperates with tumornecrosis factor- $\alpha$ to induce apoptosis in tumor cells. J. Biol. Chem. 274: 13451 - 13455

43. Jobin C, Panja A, Hellerbrand C, Limuro Y, Didonato J, BrennerDA and Sartor RB (1998) Inhibition of proinflammatory molecule production by adenovirusmediated expression of a nuclear factor kB super-repressor in human intestinal epithelial cells. J. Immunol. 160: 410-418

44. Garrouste FL, Remacle-Bonnet MM, Lehmann MMA, Marvaldi JL and Pommier GJ (1997) Up-regulation of insulin/insulin-like growth factor-I hybrid receptors during differentiation of HT29-D4 human colonic carcinoma cells. Endocrinology 138: 2021-2032

45. Farrelly N, Lee YJ, Oliver J, Dive C and Streuli C (1999) Extracellular matrix regulates apoptosis in mammary epithelium through a control on insulin signaling. J. Cell. Biol. 144: 1337-1347

46. Valentinis B, Morrione A,PeruzziF, Prisco M, Reiss KandBaserga R(1999)Antiapoptotic signaling of the IGF-I receptor in fibroblasts following loss of matrix adhesion. Oncogene 18: 1827-1836

47. Clark S, Eckhardt G, Siddle K and Harrison LC (1991) Changes in insulinreceptor structure associated with trypsin-induced activation of the receptor tyrosine kinase. Biochem. J. 276: 27-33

48. Baron V, Calléja V, Ferrari P, Alengrin F and Van Obberghen E (1998) p125 $5^{\text {Fak }}$ focal adhesion kinase is a substrate for the insulin and the insulin-like growth factor-I tyrosine kinase receptors. J. Biol. Chem. 273: 7162-7168 
49. Valentinis B, Reiss Kand Baserga R(1998) Insulin-like growth factor-I-mediated survival from anoikis: role of cell aggregation and focal adhesion kinase. J. Cell Physiol. 176: 648-657

50. Parrizas M, Saltiel AR and LeRoith D (1997) Insulin-like growth factor 1 inhibits apoptosis using the phosphatidylinositol 3 '-kinase and mitogen-activated protein kinase pathways. J. Biol. Chem. 272: 154-161

51. Kulik G and Weber MJ (1998) Akt-dependent and -independent survival signaling pathways utilized by insulin-like growth factor I. Mol. Cell Biol. 18: 6711-6718

52. Beg AA and Baltimore D (1996) An essential role for NF- $\kappa$ B in preventing TNF- $\alpha-$ induced cell death. Science 274: 782-784

53. Wang CY, Mayo MW and Baldwin Jr AS (1996) TNF-and cancer therapy-induced apoptosis: potentiation by inhibition of NF- $\kappa$ B. Science 274: $784-787$

54. Barkett M and Gilmore T (1999) Control of apoptosis by Rel/NF- $\kappa$ B transcription factors. Oncogene 18: 6910-6924

55. Heck S, Lezoualc'h F, Engert S and Behl C (1999) Insulin-like growth factor-1mediated neuroprotection against oxidative stress is associated with activation of nuclear factor $\kappa$ B. J. Biol. Chem. 274: 9828-9835
56. Cheshire JL and Baldwin Jr AS (1997) Synergistic activation of NF- $\kappa$ B by tumor necrosis factor alpha and gamma interferon via enhanced $l_{\kappa} \mathrm{B} \alpha$ degradation of de novo $\mathrm{I}_{\kappa} \mathrm{B} \beta$ degradation. Mol. Cell Biol. 17: 6746-6754

57. Giardina C, Boulares H and Inan MS (1999) NSAID and butyrate sensitize a human colorectal cancer cell line to TNF- $\alpha$ and Fas ligation: the role of reactive oxygen species. Biochim. Biophys. Acta. 1448: 425-438

58. Schmid RM and Adler G (2000) NF- $\kappa B / r e l / / \kappa B$ : implications in gastrointestinal diseases. Gastroenterology 118: 1208-1228

59. Lehmann M, Rabenandrassana C, Tamura R, Lissitsky JC, Quaranta V, Pichon J and Marvaldi J (1994) A monoclonal antibody inhibits adhesion to fibronectin and vitronectin of a colon carcinoma cell line and recognizes the integrins $\alpha \mathrm{v} \beta 3, \alpha \mathrm{v} \beta 5$, and $\alpha$ v $\beta 6$. Cancer Res. 54: 2102-2107

60. Nicoletti I, Migliorati G, Pagliacci MC, Grignani F and Riccardi C (1991) A rapid and simple method for measuring thymocyte apoptosis by propidium iodide staining and flow cytometry. J. Immunol. Methods 139: 271 -279 